\title{
Novel bone morphogenetic protein 15 (BMP15) gene variants implicated in premature ovarian insufficiency
}

\author{
Fatemeh Afkhami ${ }^{1}$, Shirin Shahbazi ${ }^{1 *} \mathbb{D}$, Laya Farzadi ${ }^{2}$ and Shahla Danaei ${ }^{3}$
}

\begin{abstract}
Background: Bone morphogenetic protein 15 (BMP15) is expressed in oocytes and plays a crucial role in the reproduction of mono-ovulating species. In humans, BMP15 gene mutations lead to imperfect protein function and premature ovarian insufficiency. Here we investigated the BMP15 gene variants in a population of Iranian women with premature ovarian insufficiency. We conducted predictive bioinformatics analysis to further study the outcomes of BMP15 gene alterations.

Methods: Twenty-four well-diagnosed premature ovarian insufficiency cases with normal karyotype participated in this study. The entire coding sequence and exon-intron junctions of the BMP15 gene were analyzed by direct sequencing. In-silico analysis was applied using various pipelines integrated into the Ensembl Variant Effect Predictor online tool. The clinical interpretation was performed based on the approved guidelines.

Results: By gene screening of BMP15, we discovered p.N103K, P.A180T, and P.M184T heterozygous variants in 3 unrelated patients. The p.N103K and p.M184T were not annotated on gnomAD, 1000 Genome and/or dbSNP. These mutations were not identified in 800 Iranians whole-exome sequencing that is recorded on Iranom database. We identified the p.N103K variant in a patient with secondary amenorrhea at the age of 17, elevated FSH and atrophic ovaries. The p.M184T was detected in a sporadic case with atrophic ovaries and very high FSH who developed secondary amenorrhea at the age of 31 .

Conclusions: Here we newly identified p.N103K and p.M184T mutation in the BMP15 gene associated with idiopathic premature ovarian insufficiency. Both mutations have occurred in the prodomain region of protein. Despite prodomain cleavage through dimerization, it is actively involved in the mature protein function. Further studies elucidating the roles of prodomain would lead to a better understanding of the disease pathogenesis.
\end{abstract}

Keywords: POI, BMP15, Gene mutation, In silico analysis

\section{Background}

Premature Ovarian Insufficiency (POI) also called premature ovarian failure (POF) is considered by loss of ovarian activity before the age of 40 . It can be distinguished as primary amenorrhea with delayed menarche, secondary

*Correspondence: sh.shahbazi@modares.ac.ir

${ }^{1}$ Department of Medical Genetics, Faculty of Medical Sciences, Tarbiat Modares University, Tehran, Iran

Full list of author information is available at the end of the article amenorrhea and oligomenorrhea over 4 months. POI is diagnosed by an increase in follicle-stimulating hormone (FSH) of higher than $25 \mathrm{mIU} / \mathrm{ml}$, repeated twice over 4 weeks [1]. Antimullerian hormone (AMH) is produced by the granulosa cells of growing follicles and is of considerable value in the timely detection of POI. Ovarian reserve can be detected by transvaginal ovarian ultrasound and estimated by AMH levels in POI cases [2]. The prevalence of POI was mainly considered $1-1.5 \%$. However, a recent meta-analysis reported a global prevalence 
of $3.7 \%$ with a higher rate in medium and low developed countries [3].

In the aetiology of POI, a wide range of explanations have been considered including involvement of infectious, autoimmune, iatrogenic or genetic factors. Among them, genetic aberrations account for approximately $20-25 \%$ of cases. FMR1 permutation is the most common genetic abnormality in POI, followed by bone morphogenetic protein 15 (BMP15) gene defects [4]. BMP15 gene is located on Xp11.2 and encodes a 392- amino acid protein of transforming growth factor- $\beta$ superfamily (TGF- $\beta$ ). The protein is composed of the signal peptide, prodomain and transforming growth factor $\beta$ - like (TGF $\beta$-like) domain [5]. BMP15 is expressed in oocytes and acts synergically with growth differentiation factor 9 (GDF9) towards the regulation of folliculogenesis [6]. Using a mouse model, it has been shown that BMP15 promote follicular development along with FSH [7]. In vitro study revealed that the simultaneous addition of GDF9 and BMP15 to the culture leads to improvement of the human primordial follicles activation [8].

BMP15 peptides either form homodimers or bind to GDF9 and make heterodimers called cumulin. Dimerization occurs via the TGF $\beta$-like domain. A furin-like protease cleaves prodomain upon protein maturation, however, prodomain remains associated with secreted mature dimer. BMP15 and cumulin control the migration and proliferation of primordial germ cells through separate signal pathways $[9,10]$.

Pathogenic mutations can disrupt the transcription/ translation of BMP15 protein or weaken the interaction with GDF9 [11]. Preliminary studies on knockout models have shown that GDF-9 deficiency led to impaired folliculogenesis and infertility, while a null mutation in the $B M P-15$ gene caused only reduced fertility in female mice [12]. Subsequent studies suggested differences in BMP15 function between mice and other mammals. A study aiming to identify factors regulating ovulation rate in sheep found that heterozygous carriers of $B M P 15$ mutation had increased ovulation while homozygous were infertile [13]. Additional evidence from the porcine knockdown model confirmed that the role of BMP15 in single-ovulatory species is more pronounced than in multi-ovulatory species [14]. This difference is explained in the balance of GDF9 and BMP15. The dominance of GDF9 signaling leads to multiple ovulations and high fertility, whereas the production of BMP15 modulate primordial germ cell sensitivity to gonadotropins and leads to single ovulation, low fertility and appropriate ovarian reserve [15].

Considering the importance of BMP15 in the pathogenesis of POI, we aimed to investigate the related mutations in a population of affected Iranian women. We further conducted predictive bioinformatics analysis in a comprehensive manner, to evaluate BMP15 gene alterations linked to POI.

\section{Methods \\ Patients}

This study was approved by the Ethics Committee of Tarbiat Modares University, Tehran, Iran (IR.MODARES. REC.1399.006). The clinical interpretation was performed based on the European society of human reproduction and embryology (ESHRE) guidelines [2]. All participants delivered written informed consent before participating in the study. Physical examination, blood testing and sonography were performed as part of routine clinical workup by the experienced gynecologists. Twenty four normal-karyotype women with idiopathic secondary amenorrhea before the age of 40 were entered into our study. Based on the genetic counselling, patients were further allocated into sporadic and familial groups. Having at least two serum FSH levels higher than 25mIU/ $\mathrm{ml}$ was the main inclusion criteria. The exclusion criteria comprised any of the following: chromosomal aberrations including FMR1 premutation, personal or family history of autoimmune diseases, ovarian surgery, radiotherapy or chemotherapy. To rule out autoimmune disease, related serological tests containing thyroid peroxidase antibody, anti-tissue transglutaminase IgG and thyroglobulin antibody were checked.

\section{DNA extraction and PCR-Sequencing}

Genomic DNA was extracted from whole blood samples using the salting-out method. The purity and concentration of the extracted DNA were measured by spectrophotometry. Specific primers were designed for two exons of BMP15 using Oligo explorer and Primer Express software as follows: exon1F;GTTGTGGAGCCAGGA TGCAG, exon1R;AAGCCTGACAGTAAACCCACC, exon2F;AATTTTAGGGCTGATTATAGC, exon2R;TTG GTACAGGATTACTTGCAG.

To perform the PCR reaction, 2X PCR master mix (Amplicon, Pishgam, Iran) containing an ultimate concentration of $1.5 \mathrm{mM} \mathrm{MgCl} 2$ was used in a final volume of $50 \mu \mathrm{l}$. The PCR program included $5 \mathrm{~min}$ initial priming at $95{ }^{\circ} \mathrm{C}$ and then 30 cycles with $30 \mathrm{~s}$ at $95^{\circ} \mathrm{C}, 30 \mathrm{~s}$ at $59{ }^{\circ} \mathrm{C}, 30 \mathrm{~s}$ at $72{ }^{\circ} \mathrm{C}$ with a final extension of $72{ }^{\circ} \mathrm{C}$ for $10 \mathrm{~min}$. The PCR products were electrophoresed on $1.5 \%$ agarose gel along with the 100 base pairs DNA marker. Bi-directional Sanger sequencing was performed on all samples across two coding exons and flanking intronic sequences. Sanger sequencing results were interpreted using the Chromas software version 2.01. 
In silico analysis

The probable pathogenic effect of the amino acid changes was detected by SIFT, PolyPhen, etc., which were integrated into the Ensembl Variant Effect Predictor (VEP) https://asia.ensembl.org/Homo_sapiens/Tools/VEP?db= core. The prevalence of the variants was checked on the
Iranome website http://www.iranome.ir/. The Iranome browser represents whole-exome sequencing data of 800 healthy individuals from eight Iranian major ethnic groups with the approximate 1:1 Female/Male ratio. All samples were selected from individuals who were $>30$ years old to reduce the bias of late-onset Mendelian

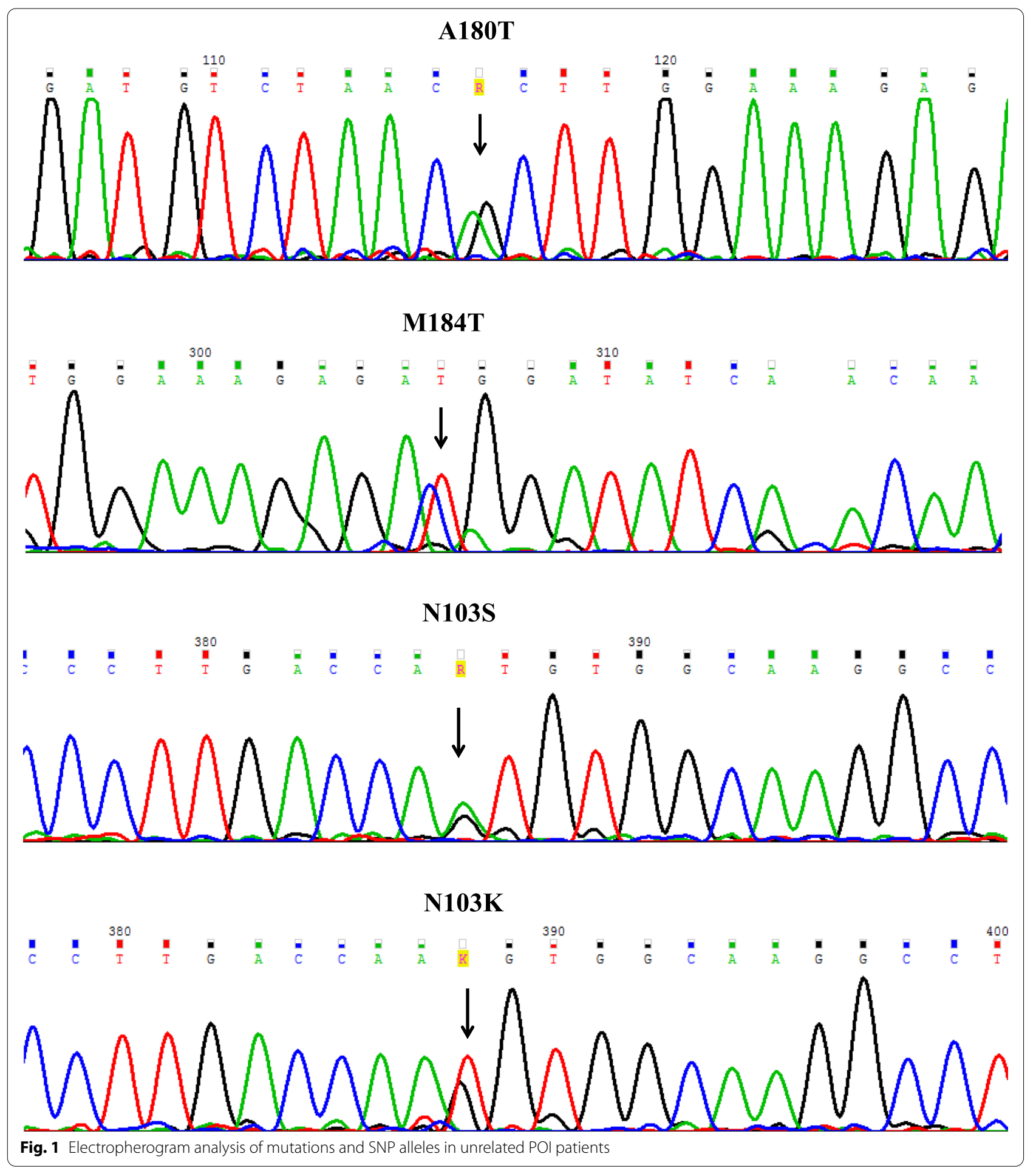


Table 1 Identified variants and clinical characteristics of the patients according to the ESHRE guideline

\begin{tabular}{|c|c|c|c|c|c|c|c|c|}
\hline Variant & $\begin{array}{l}\text { Current Age } \\
\text { (yrs.) }\end{array}$ & $\begin{array}{l}\text { Age at } \\
\text { Menarche } \\
\text { (yrs.) }\end{array}$ & $\begin{array}{l}\text { Patterns } \\
\text { of menses } \\
\text { at } \\
\text { Diagnosis }\end{array}$ & $\begin{array}{l}\text { Age at } \\
\text { Diagnosis } \\
\text { (yrs.) }\end{array}$ & $\begin{array}{l}\text { Sonographic finding at } \\
\text { Diagnosis }\end{array}$ & $\begin{array}{l}\text { FSH } \\
(\mathrm{mlU} / \mathrm{mL}) \\
\text { at } \\
\text { Diagnosis }\end{array}$ & $\begin{array}{l}\text { AMH } \\
(\mathrm{ng} / \mathrm{ml}) \\
\text { at } \\
\text { Diagnosis }\end{array}$ & Maternal Parity \\
\hline p.N103S & 29 & 13 & Secondary Amenorrhea & 17 & Atrophic Ovaries & 135 & 0.01 & - \\
\hline p.N103K & 20 & 16 & Secondary Amenorrhea & 17 & Atrophic Ovaries & 40 & 0.82 & - \\
\hline p.A180T & 42 & 13 & $\begin{array}{l}\text { Irregular menses } \\
\text { (Oligomenorrhea more } \\
\text { than } 18 \text { months) }\end{array}$ & 39 & Normal Ovaries & 30 & 0.03 & One Child \\
\hline p.M184T & 33 & 16 & Secondary Amenorrhea & 31 & $\begin{array}{l}\text { Atrophic } \\
\text { Ovaries }\end{array}$ & 100 & 0.01 & One Child \\
\hline
\end{tabular}

disorders. The mean age at blood draw was $50.61 \pm 9.33$, and the age range $30-84$ years old in the whole project [16].

Structural modeling of BMP15 wild-type and missense variants were computed by the SWISS-MODEL servers. The protein models were assessed using the Ramachandran plot from the MolProbity program.

\section{Statistical analyses}

The collected clinical data were statistically analyzed using SPSS version 24 with a significance level chosen at $5 \%$. Correlation studies of the quantitative and qualitative data were performed by ANOVA and Chi-square tests, respectively.

\section{Results}

\section{Clinical status of patients}

All of the patients had spontaneously entered menarche and none of the patients was exhibited primary amenorrhea. The mean age at menarche was calculated at $13.12 \pm 1.56$ years old. The mean age at POI diagnosis was $26.84 \pm 9.07$ years old ranged from 12 to 39 . Median and mean levels of serum FSH were 40.8 and 75.92 $\mathrm{mIU} / \mathrm{ml}$, respectively. The analyses of $\mathrm{AMH}$ serum levels were available for 19 out of 24 patients and the majority of them were below $0.02 \mathrm{ng} / \mathrm{ml}$. The sonographic evaluation revealed that $79.16 \%$ of the patients had atrophic ovaries and $20.83 \%$ had normal ovarian pattern. Patients' interviews and genetic counselling disclosed that 6 out of 24 cases had a family history of menstrual irregularities, infertility and/or secondary amenorrhea.

\section{BMP15 genotyping}

As shown in Fig. 1, by the PCR-sequencing analysis of BMP15, we discovered p.N103K, p.A180T, and p.M184T heterozygous variants in 3 unrelated patients. This is the first report of the link between p.N103K and p.M184T to the POI pathogenesis.
Table 2 Correlation between the $-9 \mathrm{G}$ polymorphism and clinicopathological parameters of the patients,

\begin{tabular}{|c|c|c|c|c|}
\hline \multirow[t]{2}{*}{ Clinical Indicators } & \multicolumn{2}{|c|}{-9G Polymorphism } & \multirow[t]{2}{*}{$\mathbf{P}$} & \multirow[t]{2}{*}{ chi-square } \\
\hline & Yes (\%) & No (\%) & & \\
\hline Age at menopause (yrs.) & & & .47 & 0.50 \\
\hline$<30$ & $3(42.9)$ & $10(58.8)$ & & \\
\hline$\geq 30$ & $4(57.1)$ & $7(41.2)$ & & \\
\hline Age at menarche (yrs.) & & & .56 & 0.33 \\
\hline$<13$ & $5(71.4)$ & $10(58.8)$ & & \\
\hline$\geq 13$ & $2(28.6)$ & $7(41.2)$ & & \\
\hline FSH levels (mIU/ml) & & & .02 & 4.88 \\
\hline$<40$ & $3(42.9)$ & $1(5.9)$ & & \\
\hline$\geq 40$ & $4(57.1)$ & $16(94.1)$ & & \\
\hline AMH levels (ng/ml) & & & .07 & 3.26 \\
\hline$<.02$ & $3(50)$ & $10(76.9)$ & & \\
\hline$\geq .02$ & $3(50)$ & $3(23.1)$ & & \\
\hline Sonographic findings & & & 61 & 0.25 \\
\hline Normal Ovaries & $1(14.3)$ & $4(23.5)$ & & \\
\hline Atrophic Ovaries & $6(85.7)$ & $13(76.5)$ & & \\
\hline
\end{tabular}

The patient carrier of p.N103K variant entered menarche at the age of 16 and secondary amenorrhea happened when she was at the age of 17 . As specified in Table 1, elevated FSH levels and a low normal range of $\mathrm{AMH}$ were detected in this patient. The sonographic evaluation exhibited an atrophic ovaries pattern. She was born from a consanguineous background without any indication of POI or related conditions in her family members.

p.M184T was detected in a sporadic POI patient who was prematurely menopaused at the age of 31 . High FSH levels of $100 \mathrm{mIU} / \mathrm{ml}$ and very low levels of $\mathrm{AMH}$ were detected by hormonal profiling. Ultrasound examination showed an atrophic pattern in both ovaries. Detailed family history revealed that the parents were not relatives and there was no history of POI and/or related disorders among her relatives. 
Table 3 Variants annotation, allele frequencies and in-silico prediction of nonsynonymous missense alterations of BMP15

\begin{tabular}{|c|c|c|c|c|c|c|c|c|c|}
\hline Reference & $\begin{array}{l}\text { Position/ } \\
\text { Substitution }\end{array}$ & Amino acids & $\begin{array}{l}\text { Existing } \\
\text { variant }\end{array}$ & $\mathrm{AF}$ & $\begin{array}{l}\text { gnom } A D \\
A F\end{array}$ & Iranome AF & SIFT & PolyPhen & $\begin{array}{l}\text { CADD } \\
\text { PHRED }\end{array}$ \\
\hline [20] & $\begin{array}{l}13 \mathrm{~A} / \mathrm{C} \\
50,910,796 \\
\text { AGT/CGT }\end{array}$ & S5R & $\begin{array}{l}\text { rs113099187 } \\
\text { CM0910176 }\end{array}$ & 0.0358 & 0.009278 & - & $\begin{array}{l}0.01 \\
\text { Deleterious }\end{array}$ & $\begin{array}{l}0.368 \\
\text { Benign }\end{array}$ & 13.19 \\
\hline [19] & $\begin{array}{l}181 \mathrm{C} / \mathrm{T} \\
50,910,964 \\
\mathbf{C G G} / \mathbf{T G G}\end{array}$ & R61W & $\begin{array}{l}\text { rs144392417 } \\
\text { CM061653 }\end{array}$ & - & - & - & $\begin{array}{l}0.24 \\
\text { Tolerated }\end{array}$ & $\begin{array}{l}0 \\
\text { Benign }\end{array}$ & 9.513 \\
\hline [21] & $\begin{array}{l}202 \mathrm{C} / \mathrm{T} \\
50,910,985 \\
\mathbf{C G G} / \mathbf{T G G}\end{array}$ & R68W & $\begin{array}{l}\text { rs104894763 } \\
\text { CM061661 }\end{array}$ & 0.0005 & 0.0006997 & - & $\begin{array}{l}0 \\
\text { Deleterious }\end{array}$ & $\begin{array}{l}0.877 \\
\text { Possibly damag- } \\
\text { ing }\end{array}$ & 22.4 \\
\hline [19] & $\begin{array}{l}226 \mathrm{C} / \mathrm{T} \\
50,911,009 \\
\text { CGT/TGT }\end{array}$ & R76C & $\begin{array}{l}\text { rs104894766 } \\
\text { CM061662 } \\
\text { COSV53141666 } \\
\text { COSV99399454 }\end{array}$ & 0.0013 & 0.0004129 & 0.005625 & $\begin{array}{l}0 \\
\text { Deleterious }\end{array}$ & $\begin{array}{l}0.959 \\
\text { Probably damag- } \\
\text { ing }\end{array}$ & 22.8 \\
\hline [19] & $\begin{array}{l}\text { 227G/A } \\
50,911,010 \\
\text { CGT/CAT }\end{array}$ & $\mathrm{R} 76 \mathrm{H}$ & $\begin{array}{l}\text { rs1557279925 } \\
\text { CM061656 } \\
\text { COSV53140125 }\end{array}$ & - & $1.977 \mathrm{e}-05$ & - & $\begin{array}{l}0.06 \\
\text { Tolerated }\end{array}$ & $\begin{array}{l}0.959 \\
\text { Probably damag- } \\
\text { ing }\end{array}$ & 20.8 \\
\hline [22] & $\begin{array}{l}242 \mathrm{~A} / \mathrm{G} \\
50,911,025 \\
\text { CAT/CGT }\end{array}$ & $\mathrm{H} 81 \mathrm{R}$ & rs781801740 & - & - & - & $\begin{array}{l}0.47 \\
\text { Tolerated }\end{array}$ & $\begin{array}{l}0.001 \\
\text { Benign }\end{array}$ & 0.010 \\
\hline \multirow[t]{2}{*}{ [19] } & $\begin{array}{l}308 \text { A/G } \\
50,911,091 \\
\text { AAT/AGT }\end{array}$ & N103S & $\begin{array}{l}\text { rs41308602 } \\
\text { CM1513124 } \\
\text { COSV53140249 }\end{array}$ & 0.0283 & 0.05707 & 0.07500 & $\begin{array}{l}0.3 \\
\text { Tolerated }\end{array}$ & $\begin{array}{l}0 \\
\text { Benign }\end{array}$ & 0.190 \\
\hline & $\begin{array}{l}309 T / G \\
50,911,092 \\
\text { AAT/AAG }\end{array}$ & N103K & - & - & - & - & $\begin{array}{l}0.35 \\
\text { Tolerated }\end{array}$ & $\begin{array}{l}0.006 \\
\text { Benign }\end{array}$ & 3.452 \\
\hline [23] & $\begin{array}{l}\text { G/C 50,915,834 } \\
\text { GTT/CTT }\end{array}$ & V136L & rs1387861526 & - & $5.465 e-06$ & - & $\begin{array}{l}0.02 \\
\text { Deleterious }\end{array}$ & $\begin{array}{l}0.292 \\
\text { Benign }\end{array}$ & 15.84 \\
\hline [20] & $\begin{array}{l}413 G / A \\
50,915,841 \\
\text { CGC/CAC }\end{array}$ & $\mathrm{R} 138 \mathrm{H}$ & $\begin{array}{l}\text { rs371418883 } \\
\text { CM092909 } \\
\text { COSV53139787 }\end{array}$ & - & $3.281 e-05$ & - & $\begin{array}{l}0.56 \\
\text { Tolerated }\end{array}$ & $\begin{array}{l}0.854 \\
\text { Possibly damag- } \\
\text { ing }\end{array}$ & 9.814 \\
\hline [20] & $\begin{array}{l}443 \mathrm{~T} / \mathrm{C} \\
50,915,871 \\
\text { CTC/CCC }\end{array}$ & L148P & $\begin{array}{l}\text { rs114823607 } \\
\text { CM061658 }\end{array}$ & 0.0109 & 0.003174 & - & $\begin{array}{l}0 \\
\text { Deleterious }\end{array}$ & $\begin{array}{l}0.987 \\
\text { Probably damag- } \\
\text { ing }\end{array}$ & 23.0 \\
\hline \multirow[t]{2}{*}{ [21] } & $\begin{array}{l}\text { 538G/A } \\
\text { 50,915,966 } \\
\text { GCT/ACT }\end{array}$ & A180T & $\begin{array}{l}\text { rs104894767 } \\
\text { CM061654 } \\
\text { CX062295 } \\
\text { COSV53141311 }\end{array}$ & 0.0032 & 0.01001 & 0.006875 & $\begin{array}{l}0.33 \\
\text { Tolerated }\end{array}$ & $\begin{array}{l}0.007 \\
\text { Benign }\end{array}$ & 0.059 \\
\hline & $\begin{array}{l}551 T / C \\
50,915,979 \\
\text { ATG/ACG }\end{array}$ & M184T & - & - & - & - & $\begin{array}{l}0.13 \\
\text { Tolerated }\end{array}$ & $\begin{array}{l}0.003 \\
\text { Benign }\end{array}$ & 7.245 \\
\hline [22] & $\begin{array}{l}581 T / C \\
50,916,009 \\
\text { TTC/TCC }\end{array}$ & F194S & rs141218518 & 0.0008 & 0.002045 & 0.001250 & $\begin{array}{l}0.09 \\
\text { Tolerated }\end{array}$ & $\begin{array}{l}0.003 \\
\text { Benign }\end{array}$ & 13.02 \\
\hline [19] & $\begin{array}{l}\text { 588T/A 50,916,016 } \\
\text { AAT/AAA }\end{array}$ & N196K & CM061651 & - & - & - & $\begin{array}{l}0.07 \\
\text { Tolerated }\end{array}$ & $\begin{array}{l}0.027 \\
\text { Benign }\end{array}$ & 6.408 \\
\hline [22] & $\begin{array}{l}595 \mathrm{G} / \mathrm{A} \\
50,916,023 \\
\text { GGA/AGA }\end{array}$ & G199R & $\begin{array}{l}\text { rs782378869 } \\
\text { COSV53142031 }\end{array}$ & - & $2.181 e-05$ & - & $\begin{array}{l}0.54 \\
\text { Tolerated }\end{array}$ & $\begin{array}{l}0.018 \\
\text { Benign }\end{array}$ & 0.415 \\
\hline [24] & $\begin{array}{l}598 \mathrm{C} / \mathrm{T} \\
50,916,026 \\
\text { CAC/TAC }\end{array}$ & $\mathrm{H} 200 \mathrm{Y}$ & rs202165852 & 0.0003 & 0.0002781 & - & $\begin{array}{l}0.53 \\
\text { Tolerated }\end{array}$ & $\begin{array}{l}0.001 \\
\text { Benign }\end{array}$ & 2.424 \\
\hline [19] & $\begin{array}{l}\text { 617G/A } \\
50,916,045 \\
\text { CGT/CAT }\end{array}$ & $\mathrm{R} 206 \mathrm{H}$ & $\begin{array}{l}\text { rs782516193 } \\
\text { CM061657 }\end{array}$ & - & $6.543 e-05$ & - & $\begin{array}{l}0.46 \\
\text { Tolerated }\end{array}$ & $\begin{array}{l}0.003 \\
\text { Benign }\end{array}$ & 0.734 \\
\hline [19] & $\begin{array}{l}661 \mathrm{~T} / \mathrm{C} \\
50,916,089 \\
\mathbf{T G G} / \mathbf{C G G}\end{array}$ & W221R & $\begin{array}{l}\text { rs375284458 } \\
\text { CM061659 }\end{array}$ & 0.0003 & 0.000398 & - & $\begin{array}{l}0.13 \\
\text { Tolerated }\end{array}$ & $\begin{array}{l}0.174 \\
\text { Benign }\end{array}$ & 11.79 \\
\hline
\end{tabular}


Table 3 (continued)

\begin{tabular}{|c|c|c|c|c|c|c|c|c|c|}
\hline Reference & $\begin{array}{l}\text { Position/ } \\
\text { Substitution }\end{array}$ & Amino acids & $\begin{array}{l}\text { Existing } \\
\text { variant }\end{array}$ & AF & $\begin{array}{l}\text { gnom } A D \\
A F\end{array}$ & Iranome AF & SIFT & PolyPhen & $\begin{array}{l}\text { CADD } \\
\text { PHRED }\end{array}$ \\
\hline [25] & $\begin{array}{l}704 \mathrm{~A} / \mathrm{G} \\
50,916,132 \\
\text { TAT/TGT }\end{array}$ & Y235C & $\begin{array}{l}\text { rs104894765 } \\
\text { CM041254 }\end{array}$ & - & - & - & $\begin{array}{l}0 \\
\text { Deleterious }\end{array}$ & $\begin{array}{l}0.95 \\
\text { Probably damag- } \\
\text { ing }\end{array}$ & 22.7 \\
\hline [24] & $\begin{array}{l}985 \mathrm{C} / \mathrm{T} \\
50,916,413 \\
\mathbf{C G C / T G C}\end{array}$ & R329C & $\begin{array}{l}\text { rs782375794 } \\
\text { CM100080 } \\
\text { COSV99399521 }\end{array}$ & - & $1.653 e-05$ & - & 0.02 Deleterious & $\begin{array}{l}0.916 \text { Probably } \\
\text { damaging }\end{array}$ & 22.5 \\
\hline$[26]$ & $\begin{array}{l}986 \mathrm{G} / \mathrm{A} \\
50,916,414 \\
\text { CGC/CAC }\end{array}$ & $\mathrm{R} 329 \mathrm{H}$ & rs782306478 & - & $1.1 \mathrm{e}-05$ & - & $\begin{array}{l}0.57 \\
\text { Tolerated }\end{array}$ & $\begin{array}{l}0.007 \\
\text { Benign }\end{array}$ & 0.095 \\
\hline [27] & $\begin{array}{l}\text { 1070G/A } \\
50,916,498 \\
\text { TGT/TAT }\end{array}$ & C357Y & rs1557280378 & - & 1.097e-05 & - & $\begin{array}{l}0 \\
\text { Deleterious }\end{array}$ & $\begin{array}{l}1 \\
\text { Probably damag- } \\
\text { ing }\end{array}$ & 24.3 \\
\hline
\end{tabular}

$A F$ Frequency of existing variants in 1000 genomes combined population, gnomAD AF Frequency of existing variants in gnomAD exomes combined population, Iranome AF Allele frequency in Iranome database

We identified p.A180T in a 42-years-old patient who was a descendant of consanguineous marriage with a familial history of POI. She had been diagnosed at age of 39 following a history of oligomenorrhea for more than 18 months. The hormonal assessment showed high FSH and very low AMH levels. The sonographic evaluation indicated normal ovarian status (Table 1).

We also detected two known variants of BMP15; c.-9 C > G and p.N103S [17]. Previous studies from Syria and India reported the p.N103S, in both cases and controls $[18,19]$. This variant is mentioned in the ClinVar database as a benign variant causing ovarian dysgenesis. The annotation of its corresponding allele, c.308 A> G showed an allele frequency of 0.057 and 0.028 in gno$\mathrm{mAD}$ and 1000 Genome, respectively. Iranome browser specified a high c.308 A $>$ G allele frequency of 0.075 in the Iranian population. In our study 1 out of 24 patients (1/48 alleles) was the carrier of this SNP variant.

\section{rs3810682, c.-9 C > G}

The 5 -UTR variant, c. -9 C > G, was detected in $29.16 \%$ of the patients, all in heterozygous status including 2 compound heterozygous with p.A180T and p.N103S. Statistical analysis was performed to calculate the correlation between c.-9 C>G SNP and clinicopathological parameters of the patients. Table 2 shows a statistically significant association between c.-9 $\mathrm{C}>\mathrm{G}$ SNP and patients FSH levels ( $p$ value $=0.02)$.

\section{In-silico analysis}

Further in-silico analysis was conducted to search the effects of the newly identified p.N103K and p.M184T on protein biogenesis and function. Table 3 lists the insilico predicted values of these mutations in comparison to previously reported nonsynonymous missense alterations of $B M P 15$. The indicated data were extracted from the Ensembl VEP online tool.

The newly identified p.N103K was not annotated on gnomAD, 1000 Genome or dbSNP. Investigation on the Iranome database revealed that p.N103K did not occur in 800 healthy Iranians. The SIFT and PolyPhen results showed scores of 0.35 and 0.006 , respectively. In the same way, the p.M184T new mutation was not annotated in databases. Bioinformatics analysis showed scores of 0.13 and 0.003 by the SIFT and PolyPhen prediction tools, respectively.

Figure 2 shows the conserved score of the M184 and N103 residues among different species indicating a higher score for M184. Both mutations are located in the secondary structure elements of the prodomain (Fig. 3B), which are essential for regulating mature protein production, secretion, and activity. M184 and N103 are present in $\beta 6$ and $\beta 1^{\prime}$ sheet of the peptide structure, respectively [26]. As shown in Fig. 3 A, M184 and A180 are situated in the same $\beta$-sheet of the peptide structure.

\section{Modelling and Mapping of the wild-type and missense variants}

Figure 4 A shows molecular modeling of wild-type M184 and N103 as compared with mutant T184 and K103, respectively. The results confirmed the localization of amino acids on the protein $\beta$-sheet structures. Figure 4B provides Ramachandran plots exhibiting $\Phi / \Psi$ backbone dihedral angles of the wild- type and mutant proteins. The wild-type showed $88.4 \%$ and $4.03 \%$ residues in the favored and outliers regions of the plot. The generated model for M184T was found to have fewer residues in the favored region (87.6\%). The Rotamer Outliers was also increased for the M184T (0.79\%) vs. wild- type $(0.16 \%)$ which indicates 
Unconserved 012345678910 Conserved

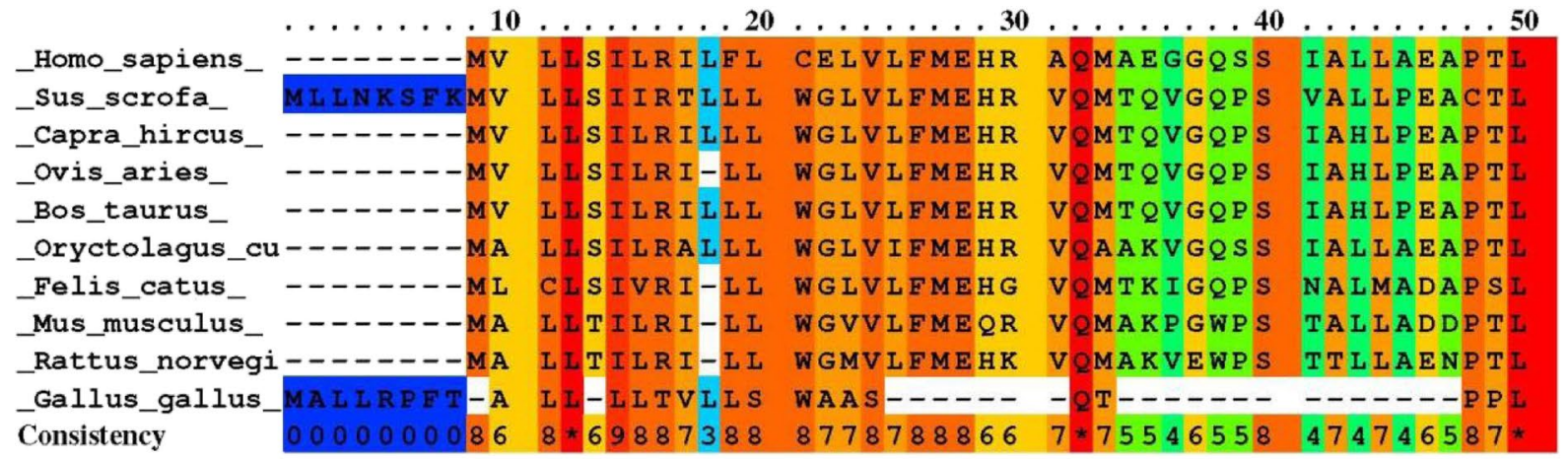

\begin{tabular}{|c|c|c|c|c|c|}
\hline & & & & & \\
\hline Homo & L IEE L LEES & PGEQPRK-PR & L L GHS L R Y ML & ELYRR A DSH & ENRTIG \\
\hline Sus_scr & L I RE L LEEA & P GKQQRK-PQ & VI GHPLRYML & ELYQR SADAR & ENRTIG \\
\hline Capra_h & L I QE L LEEA & P GKQQRK-PR & VL GHPLRYML & ELYQR S A DAS & ENRTIG \\
\hline Ovis_a. & L I QE L LEEA & P GKQQRK-PR & VL G H P L Y Y L & ELYQRSADAS & E NRTIG \\
\hline Bos_ta & L I $Q E I L E A$ & P GKQQRK-PR & I L GHPLRYML & EL YQR S A D A S & ENRTIG \\
\hline _oryc & L I RE L LEEA & PDKQQRK-PQ & L Q GHP L & E L Y QR S A D P H & E NRT I G \\
\hline Feli & L I RE L LEGA & P GKQQRK-P P & VLGHPLRYML & ELYQRSADAR & ENRTIG \\
\hline Mus & $S I L D I A K E A$ & P GKE-MK-QW & PQGYPLRYML & K L Y HRS ADPH & ENRTIG \\
\hline Rat & S S L D L A KEA & P GKE-MK-QW & P Q G Y P L Y ML & KL Y QR S A D P H & ENRTIG \\
\hline Gal & $L \perp Q A$ & PGSQGWRGGA & A S G QP L R Y M & E L Y QRAADHE & RGRSLS \\
\hline & $; 779$ & 63 & 55 & $8 \star \star 7 \star 9 \star \star 55$ & 98 \\
\hline _Hom & ATMVR: & TNVARPHRGT & WHIQI L GEPL & GLYQLV & $V$ V Y RH H \\
\hline Sus & ATMVRLVRPL & VNGARPI & QTLDFPL & RPNRVAYQLV & VVYRHQ \\
\hline Cap & ATMVRLVRPL & AS VARPLRGS & WHIQTLDFPL & RPNRVAYQLV & VVYRHQI \\
\hline Ovis & A TMVRL VRPL & AS VARPLRGS & WHIQTLDFPL & R VA Y Q L V & VVYRHQI \\
\hline Bos & ATMVRLVRPL & A S VARPLRGS & WH I QTLDFPI & VAYQLV & IVYRHQL \\
\hline oryc & ATMVR & ANVARP L R GP & KTLDFPL & RPNRVAYQLV & VVYRHQL \\
\hline Fel & ATMVRLVRPL & A DVARPLRGP & WNIQTLDFPL & RPNRVAYQLV & IVYRHQL \\
\hline Mus & A KMVR: & ANTVRPE & QTLDFPL & A SNQVAYELI & VYRHQL \\
\hline Rat & VRI I K P S & R L L R G P & [ QTLDFPL & A S NEVAYQLI & HQL \\
\hline Ga & TNTVRLVQAA & SHGGQPWAGR & QP L TYRL & DAQSEAEHLL & A Y P QS I \\
\hline Consi & 9786 & 5 & * 798 * & $38 * 8$ & 87 \\
\hline & & & & & \\
\hline _Ho & QL T R F & VEPWVQ & S SEGDS & SKP S LMS & L VQ \\
\hline Sus & $\mathrm{H} L \mathrm{AP} F \mathrm{~F} \perp \mathrm{SCH}$ & VEPW I QF & SHFPSSRGS & L K P S L L Q A W & MDV: \\
\hline$s_{-} 1$ & HITHSH S SCH & VEP WG Q K & S S GRGS & P KP S L L K TW & HVG \\
\hline Ovi & $\mathrm{HLTHSH} \mathrm{T} \mathrm{SH}$ & VEPWVQKSPT & NHFPSSRGS & SKP S L L P KTW & $M D I M$ \\
\hline Bos_t & H I THSH $\mathrm{S} \mathrm{SCH}$ & VEPWVQKSPT & NHFPSSRGS & S K P S L L P KAW & $T E M D I D$ \\
\hline Oryct & $\mathrm{HLAHF} \perp \mathrm{SCH}$ & VEPWVQKSPT & NHIP-PGRGS & AKPSLMSKAW & MEMDITQHIQ \\
\hline Fel & $\mathrm{H} L \mathrm{ARFH}$ L P CH & VEPWVQKGPT & NHFPSSGGYS & SKP SMLYKAW & TEMDITQHV- \\
\hline _Mus & $\mathrm{H} L \mathrm{VNYHISCH}$ & VETWVPKCRT & KH L P S K S GS & SKP SPMSKAW & TEIDITHCIQ \\
\hline Rat & $\mathrm{H} I \mathrm{VHYHISCH}$ & VEPWVPKCRT & KHFP-SKSGS & AKPSSVSKAW & REMN ITHCIQ \\
\hline Ga & $P L P R G R L L C A$ & VELL $----P A$ & A KAPAVLLSP & TAPS -- RHGW & $A E A D I T P Y L S$ \\
\hline consistency & $7 \star 5546 \star 7 \star 8$ & $\star \star 78658468$ & $686 * 574468$ & 46467 * & $5 \star 79965484$ \\
\hline
\end{tabular}

Fig. 2 The conservation scores of the first 200 amino acids of BMP15 protein among different species. Blue and red lines show the two side of the spectrum from amino acid insertions or differences with the lowest degree of conservation to sequence identity among different species, respectively. Black arrows indicate the score of $\mathrm{N} 103$ and M184 residues, respectively. Analyzed on https://www.ibi.vu.nl/programs/pralinewww/ 


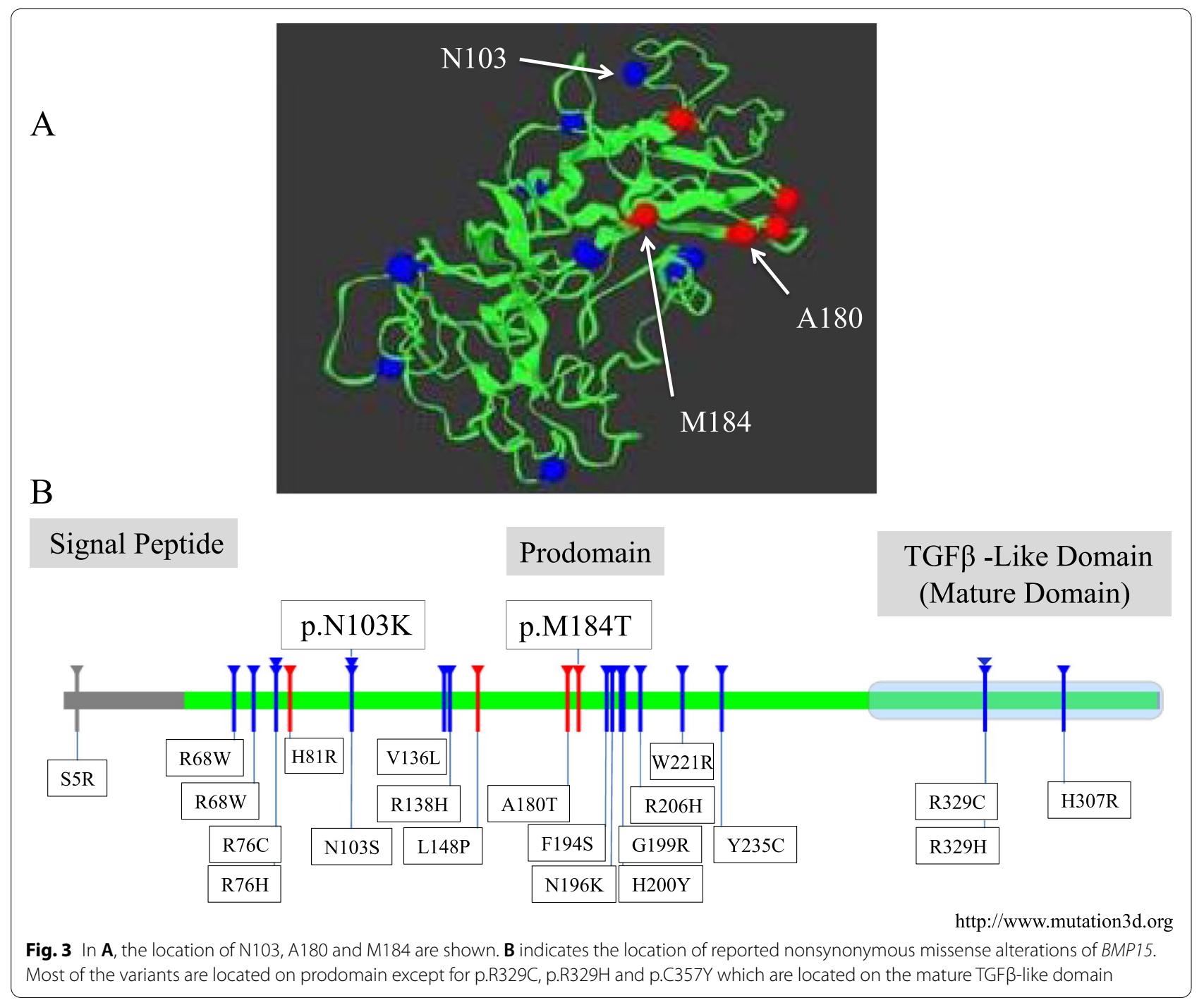

a decrease in protein stability. The mutant N103K displayed the same configuration as that of the wild-type structure.

\section{Segregation analysis of the p.A180T}

As mentioned earlier, p.A180T was found in a patient with a family history of POI. The c.538G'A missense variant located in exon 2 of BMP15 is presented in databases as the rs104894767. As illustrated in the family pedigree, two older sisters of the proband were also reached menopause before the age of 40 , however, their mother entered physiological menopause at the age of 55 . By Sanger sequencing, the c.538G'A variant was analyzed in the female family members. The obtained results indicated a heterozygote alteration in the 64-years-old mother and one of the affected sisters who was menopaused at 35 . The other POI sister with menopause at 40 and the 43-years-old healthy sister with regular menses did not carry the p.A180T variant (Fig. 5).

\section{Discussion}

In this study, we provided the molecular analysis of the BMP15 gene in a series of unrelated Iranian women with idiopathic POI. Our results revealed two novel variants; p.N103K and p.M184T as well as one known substitution; p.A180T.

With the development of next-generation sequencing, several new genes have been linked to the disease pathogenesis which supports the concept of POI heterogeneity. Investigation of copy number variations led to the identification of microdeletions/microduplications on multiple chromosomal regions. Using high-resolution SNP arrays a $4 \mathrm{MB}$ deletion in Xp11.23-p11.22 was discovered in a patient with secondary amenorrhea at the age of 34 . This 


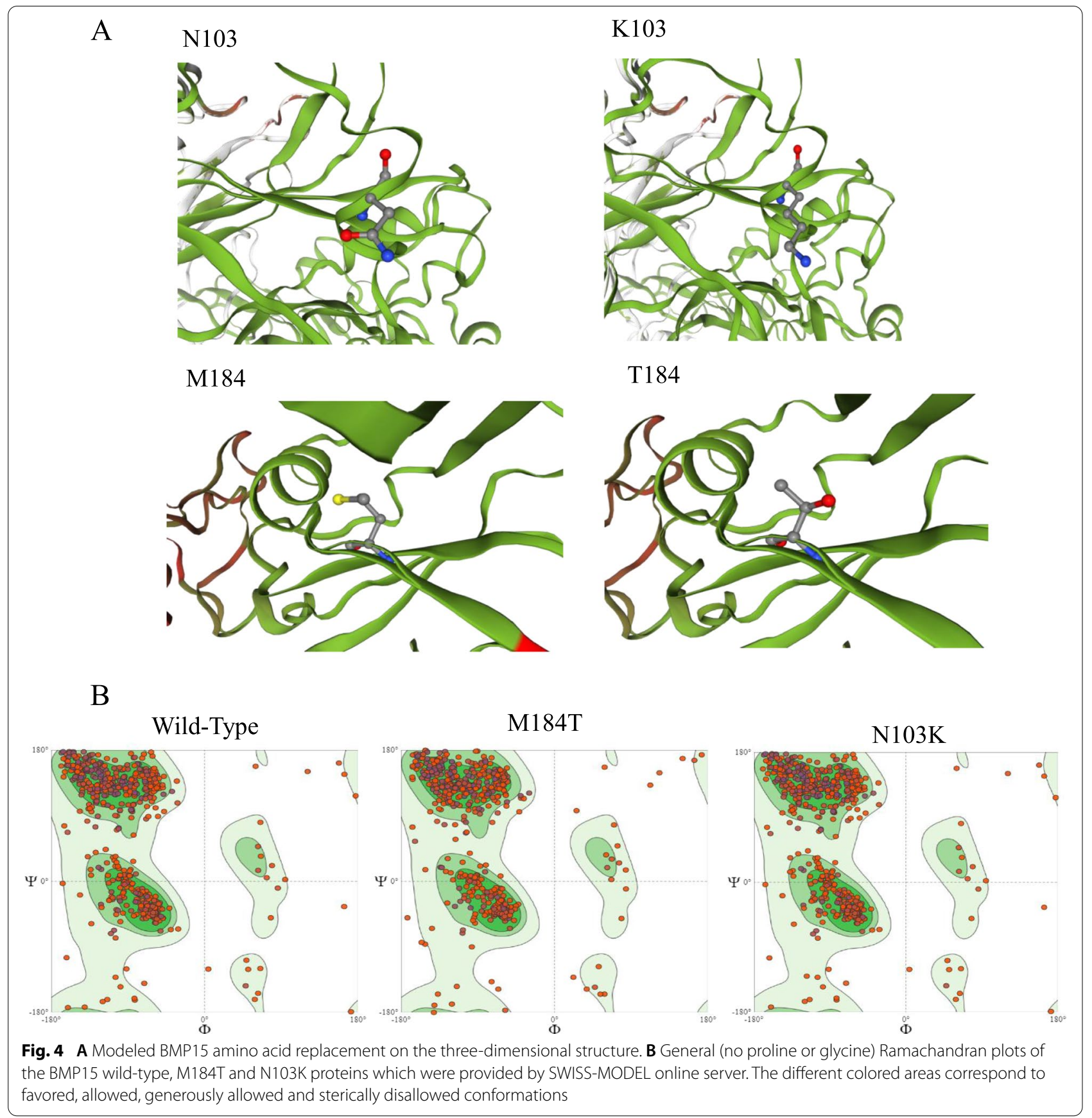

deletion consists of 65 genes, including the entire $B M P 15$ [28]. A more recent study reported the deletion of both paternal and maternal copies of BMP15 in a 16-yearold patient with primary amenorrhea and FSH levels of $141 \mathrm{mIU} / \mathrm{ml}$. The deletion expanded $36 \mathrm{~KB}$ and contained the entire BMP15 in the Xp11.22 region. In addition, the study showed intragenic duplication of the tumor protein P63 (TP63) gene in two sisters who were also the carrier of BMP15 p.Y235C [29]. Remarkably, p.Y235C is the first discovered BMP15 mutation that was reported in 2004 in the heterozygous Italian sisters [25]. The same research group further identified p.R68W and p.A180T alterations in non-familial POI patients in 2006 [21]. In 2009 they repeated the $B M P 15$ gene screening in 300 patients and found p.R138H and p.L148P in the prodomain region. They also reported p.S5R mutation which is localized in the signal peptide of the nascent protein. By conducting a functional in vitro assay in the human granulosa cell line, 


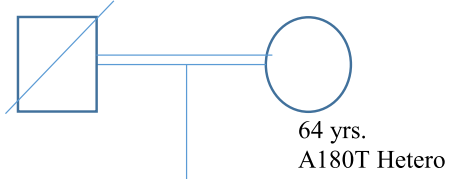

II

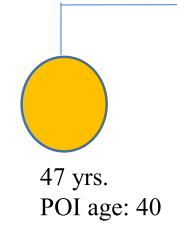

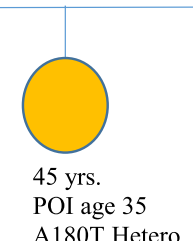

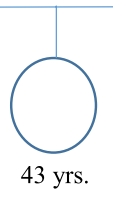

A180T Hetero
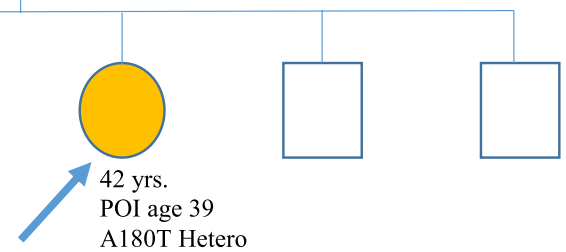

A180T Hetero

Fig. 5 Family pedigree shows the proband (arrow) and the rest of the affected family members with POI presented in colored circles. Genotyping of BMP15 is indicated below the symbols, with the A180T heterozygote variant

they disclosed that p.R68W, p.L148P and p.R138H cause the reduction of mature BMP15 protein. While p.A180T or p.S5R displayed no deleterious impact on protein secretion or function [20]. However, in 2017, Patiño et al. estimated four-fold lower activity of p.A180T compared to wild-type BMP15. They evaluated the expression and activity of 10 BMP15 variants and showed that these nucleotide changes could reduce mature peptide production, activity or synergy with GDF9 [26].

The obtained results regarding p.A180T remained conflicting, as in several studies it was only detected in patients [11, 19], while in others, both in patients and controls [22, 30]. Based on the Iranome database, the allele frequency of the p.A180T in the Iranian healthy population is 0.006 . In our study, we found the p.A180T variant in a POI patient who was born from a consanguineous marriage with a family history of POI. Segregation analysis confirmed that the p.A180T could not be the causative mutation in this family. Modifier genes and SNPs should be considered as the influential factors in the genotype/phenotype correlation.

We further identified p.N103K missense heterozygote transition. This new BMP15 mutation was detected in the offspring of first-cousin parents without any family history of POI. Our next newly identified missense heterozygote substitution; p.M184T was identified in a sporadic POI case exhibiting high FSH levels. Since p.N103K and p.M184T are not annotated in the reference databases it can be assumed that these new variants are possibly pathogenic. Their placement in the functional regions of the protein supports this conclusion.

Figure 3B indicates that p.N103K and p.M184T are localized on the prodomain region of the protein. The prodomain is cleaved during the maturation process and remains non-covalently bound to the homo or heterodimers upon secretion. The folding and dimerization of the mature protein are regulated by the prodomain [31]. It has been shown that prodomain mutations can prevent its binding to mature dimers leading to decreased BMP15 activity [32]. As mentioned previously, BMP15 reduction is correlated to increased ovulation rate and the chance of dizygotic twins' pregnancy. This increase in ovulation can eventually lead to ovarian depletion and POI [33].

It should be noted that sheep BMP15 mutations have often been occurred in the mature protein, while most human BMP15 mutations are prodomain variants [26]. Nonsynonymous missense variants of $B M P 15$ that are listed in Table 3 are prodomain alterations except for; p.R329C, p.R329H and p.C357Y which are located on the mature TGF $\beta$-like domain.

In 2018, Zhang et al. reported homozygous p.C357Y mutation in the TGF $\beta$-like domain. To our knowledge, this is the sole described homozygous nonsynonymous missense variant of the BMP15. The patient's heterozygous mother was 48 years old with normal menstrual cycles. They assumed that the mutations in the TGF $\beta$ like domain should be homozygous to cause the disease while the heterozygous mutations of the prodomain are sufficient for defective protein maturation and POI [27]. However, Patiño et al. reported another mutation in TGF $\beta$-like domain; p.R329H, in a heterozygous POI patient [26]. The p.R329C mutation of the mature subunit was reported earlier from China. The patient was a 37-year-old woman who developed secondary amenorrhea at the age of 27. The patient's mother had irregular menses and menopause at the age of 40 . The data on hetero or homozygosity of these mother and daughter is not available [24]. More recently, Rossetti et al. examined p.R329C mutation, functionally. The results showed that heterozygote p.R329C mutation led to disrupted colocalization with GDF9 and SMAD pathway activation [34].

We found p.N103K and p.M184T in the heterozygous patients, like almost all previously reported BMP15 
mutations [23]. This feature was often concluded by haploinsufficiency or negative dominance effects. However, the discovery of intragenic duplication of the TP63 in the carriers of p.Y235C has added to the complexity of interpreting the BMP15 mutations.

\section{Conclusions}

In this study, we found two new variants in the $B M P$ 15 gene that have not been reported in databases. These mutations were not identified in 800 Iranians wholeexome sequencing results available on Iranom's website.

The p.N103K and p.M184T are localized on the prodomain region of the protein. Due to the cleavage of prodomain during BMP15 maturation, bioinformatics analyzes are likely to underestimate the effects of the mutations. This is while prodomain is actively involved in the homo and heterodimers secretion and function. Further studies to elucidate the roles of the prodomain could be of great value in identifying the effects of multiple mutations reported in this region.

\section{Acknowledgements}

The author would like to thank the patients who participated in this survey.

\section{Authors' contributions}

The author's contributions are as follows FA: Project development, Data collection, Data analysis, Manuscript writing. SS: Project development, Data collection, Data analysis, Manuscript writing/editing. LF: Clinical Data collection and management, Manuscript editing. SD: Clinical Data collection and management, Manuscript editing. The author(s) read and approved the final manuscript.

\section{Funding}

Not applicable.

\section{Availability of data and materials}

The authors confirm that the data supporting the findings of this study are available within the article. Raw data of are available from the corresponding author on request.

\section{Declarations}

\section{Ethics approval and consent to participate}

All procedures performed in studies involving human participants were in accordance with the ethical standards of the institutional and/or national research committee and with the 1964 Helsinki Declaration and its later amendments or comparable ethical standards. This study was approved by the Ethics Committee of Tarbiat Modares University, Tehran, Iran (IR.MODARES. REC.1399.006). https://ethics.research.ac.ir/EthicsProposalViewEn.php?id= 130467.

\section{Consent for publication}

Patients signed informed consent regarding publishing their data.

\section{Competing interests}

The authors declare that they have no conflict of interest.

\section{Author details}

${ }^{1}$ Department of Medical Genetics, Faculty of Medical Sciences, Tarbiat Modares University, Tehran, Iran. Department of Obstetrics and Gynecology, School of Medicine, Tabriz University of Medical Sciences, Tabriz, Iran. ${ }^{3}$ Gynecology Departments, Eastern Azerbaijan ACECR ART Center, Eastern Azerbaijan Branch of ACECR, Tabriz, Iran.
Received: 17 August 2021 Accepted: 6 February 2022

Published online: 01 March 2022

\section{References}

1. Nelson LM. Clinical practice. Primary ovarian insufficiency. N Engl J Med. 2009;360(6):606-14.

2. Webber L, Davies M, Anderson R, Bartlett J, Braat D, Cartwright B, et al. ESHRE Guideline: management of women with premature ovarian insufficiency. Hum Reprod (Oxford England). 2016;31(5):926-37.

3. Golezar S, Ramezani Tehrani F, Khazaei S, Ebadi A, Keshavarz Z. The global prevalence of primary ovarian insufficiency and early menopause: a meta-analysis. Climacteric: the journal of the International Menopause Society. 2019;22(4):403-11.

4. Persani L, Rossetti R, Cacciatore C. Genes involved in human premature ovarian failure. J Mol Endocrinol. 2010;45(5):257-79.

5. Dube JL, Wang P, Elvin J, Lyons KM, Celeste AJ, Matzuk MM. The Bone Morphogenetic Protein 15 Gene Is X-Linked and Expressed in Oocytes. Mol Endocrinol. 1998;12(12):1809-17.

6. Abir R, Fisch B, Johnson MH. BMP15, fertility and the ovary. Reprod Biomed Online. 2014;29(5):525-6.

7. Salehnia M, Pajokh M, Ghorbanmehr N. Short Term Organ Culture of Mouse Ovary in the Medium Supplemented with Bone Morphogenetic Protein 15 and Follicle Stimulating Hormone: A Morphological, Hormonal and Molecular Study. J Reprod infertility. 2016;17(4):199-207.

8. Kedem A, Fisch B, Garor R, Ben-Zaken A, Gizunterman T, Felz C, et al. Growth differentiating factor 9 (GDF9) and bone morphogenetic protein 15 both activate development of human primordial follicles in vitro, with seemingly more beneficial effects of GDF9. J Clin Endocrinol Metab. 2011;96(8):E1246-54.

9. Moore RK, Shimasaki S. Molecular biology and physiological role of the oocyte factor, BMP-15. Mol Cell Endocrinol. 2005;234(1-2):67-73.

10. Peng J, Li Q, Wigglesworth K, Rangarajan A, Kattamuri C, Peterson RT, et al. Growth differentiation factor 9:bone morphogenetic protein 15 heterodimers are potent regulators of ovarian functions. 2013;110(8):E776-E85.

11. Laissue P, Christin-Maitre S, Touraine P, Kuttenn F, Ritvos O, Aittomaki K, et al. Mutations and sequence variants in GDF9 and BMP15 in patients with premature ovarian failure. Eur J Endocrinol. 2006;154(5):739-44.

12. Yan C, Wang P, DeMayo J, DeMayo FJ, Elvin JA, Carino C, et al. Synergistic roles of bone morphogenetic protein 15 and growth differentiation factor 9 in ovarian function. Mol Endocrinol (Baltimore Md). 2001;15(6):854-66.

13. McNatty KP, Juengel JL, Wilson T, Galloway SM, Davis GH. Genetic mutations influencing ovulation rate in sheep. Reprod Fertil Dev. 2001;13(7-8):549-55.

14. Qin Y, Tang T, Li W, Liu Z, Yang X, Shi X, et al. Bone Morphogenetic Protein 15 Knockdown Inhibits Porcine Ovarian Follicular Development and Ovulation. Front Cell Dev Biology. 2019;7:286.

15. McNatty KP, Moore LG, Hudson NL, Quirke LD, Lawrence SB, Reader $K$, et al. The oocyte and its role in regulating ovulation rate: a new paradigm in reproductive biology. Reprod (Cambridge England). 2004;128(4):379-86.

16. Fattahi Z, Beheshtian M, Mohseni M, Poustchi H, Sellars E, Nezhadi SH, et al. Iranome: A catalog of genomic variations in the Iranian population. Hum Mutat. 2019;40(11):1968-84.

17. Abir R, Fisch B. Invited commentary: a single nucleotide polymorphism in BMP15 is associated with high response to controlled ovarian hyperstimulation. Reprod Biomed Online. 2011;23(1):77-80.

18. Al-ajoury R, Kassem E, Al-halabi B, Moassess F, Al-achkar W. Investigation of some genetic variations in BMP15 accompanied with premature ovarian failure (POF) in Syrian women. Middle East Fertility Society Journal. 2015;20(2):91-6.

19. Dixit H, Rao LK, Padmalatha W, Kanakavalli M, Deenadayal M, Gupta N, et al. Missense mutations in the BMP15 gene are associated with ovarian failure. Hum Genet. 2006;119(4):408-15.

20. Rossetti R, Di Pasquale E, Marozzi A, Bione S, Toniolo D, Grammatico $P$, et al. BMP15 mutations associated with primary ovarian insufficiency cause a defective production of bioactive protein. Hum Mutat. 2009;30(5):804-10. 
21. Di Pasquale E, Rossetti R, Marozzi A, Bodega B, Borgato S, Cavallo L, et al. Identification of new variants of human BMP15 gene in a large cohort of women with premature ovarian failure. J Clin Endocrinol Metab. 2006;91(5):1976-9.

22. Tiotiu D, Alvaro Mercadal B, Imbert R, Verbist J, Demeestere I, De Leener A et al. Variants of the BMP15 gene in a cohort of patients with premature ovarian failure. Hum Reprod (Oxford England). 2010;25(6):1581-7.

23. Ferrarini E, De Marco G, Orsolini F, Gianetti E, Benelli E, Fruzzetti F, et al. Characterization of a novel mutation V136L in bone morphogenetic protein 15 identified in a woman affected by POI. J ovarian Res. 2021;14(1):85

24. Wang B, Wen Q, Ni F, Zhou S, Wang J, Cao Y, et al. Analyses of growth differentiation factor 9 (GDF9) and bone morphogenetic protein 15 (BMP15) mutation in Chinese women with premature ovarian failure. Clin Endocrinol. 2010;72(1):135-6.

25. Di Pasquale E, Beck-Peccoz P, Persani L. Hypergonadotropic ovarian failure associated with an inherited mutation of human bone morphogenetic protein-15 (BMP15) gene. Am J Hum Genet. 2004;75(1):106-11.

26. Patiño LC, Walton KL, Mueller TD, Johnson KE, Stocker W, Richani D, et al. BMP15 Mutations Associated With Primary Ovarian Insufficiency Reduce Expression, Activity, or Synergy With GDF9. J Clin Endocrinol Metab. 2017;102(3):1009-19.

27. Zhang W, Wang J, Wang X, Li L, Pan H, Chen B, et al. A novel homozygous mutation of bone morphogenetic protein 15 identified in a consanguineous marriage family with primary ovarian insufficiency. Reprod Biomed Online. 2018;36(2):206-9.

28. McGuire MM, Bowden W, Engel NJ, Ahn HW, Kovanci E, Rajkovic A. Genomic analysis using high-resolution single-nucleotide polymorphism arrays reveals novel microdeletions associated with premature ovarian failure. Fertil Steril. 2011;95(5):1595-600.

29. Bestetti I, Castronovo C, Sironi A, Caslini C, Sala C, Rossetti R, et al. Highresolution array-CGH analysis on $46, \mathrm{XX}$ patients affected by early onset primary ovarian insufficiency discloses new genes involved in ovarian function. Hum Reprod (Oxford England). 2019;34(3):574-83.

30. Ledig S, Röpke A, Haeusler G, Hinney B, Wieacker P. BMP15 mutations in XX gonadal dysgenesis and premature ovarian failure. Am J Obstet Gynecol. 2008;198(1):84.e1-5.

31. Belli M, Shimasaki S. Molecular Aspects and Clinical Relevance of GDF9 and BMP15 in Ovarian Function. Vitam Horm. 2018;107:317-48.

32. Inagaki K, Shimasaki S. Impaired production of BMP-15 and GDF-9 mature proteins derived from proproteins WITH mutations in the proregion. Mol Cell Endocrinol. 2010;328(1-2):1-7.

33. Otsuka F, McTavish KJ, Shimasaki S. Integral role of GDF-9 and BMP-15 in ovarian function. Mol Reprod Dev. 2011;78(1):9-21.

34. Rossetti R, Ferrari I, Bestetti I, Moleri S, Brancati F, Petrone L, et al. Fundamental role of BMP15 in human ovarian folliculogenesis revealed by nul and missense mutations associated with primary ovarian insufficiency. Hum Mutat. 2020;41(5):983-97.

\section{Publisher's Note}

Springer Nature remains neutral with regard to jurisdictional claims in published maps and institutional affiliations.

Ready to submit your research? Choose BMC and benefit from:

- fast, convenient online submission

- thorough peer review by experienced researchers in your field

- rapid publication on acceptance

- support for research data, including large and complex data types

- gold Open Access which fosters wider collaboration and increased citations

- maximum visibility for your research: over $100 \mathrm{M}$ website views per year

At BMC, research is always in progress.

Learn more biomedcentral.com/submissions 